\title{
The impact of herpes zoster and post-herpetic neuralgia on quality-of-life
}

\author{
Robert W Johnson*1, Didier Bouhassira² ${ }^{2}$ George Kassianos ${ }^{3}$, Alain Leplège ${ }^{4}$, Kenneth E Schmader ${ }^{5}$ and \\ Thomas Weinke6
}

\begin{abstract}
Background: The potentially serious nature of herpes zoster $(\mathrm{HZ})$ and the long-term complication post-herpetic neuralgia (PHN) are often underestimated. One in four people will contract herpes zoster in their lifetime, with this risk rising markedly after the age of 50 years, and affecting one in two in elderly individuals. Pain is the predominant symptom in all phases of $\mathrm{HZ}$ disease, being reported by up to $90 \%$ of patients. In the acute phase, pain is usually moderate or severe, with patients ranking $\mathrm{HZ}$ pain as more intense than post-surgical or labour pains. Up to 20\% of patients with $\mathrm{HZ}$ develop PHN, which is moderate-to-severe chronic pain persisting for months or years after the acute phase. We review the available data on the effect of $\mathrm{HZ}$ and $\mathrm{PHN}$ on patients' quality-of-life.

Discussion: Findings show that $\mathrm{HZ}$, and particularly PHN, have a major impact on patients' lives across all four health domains - physical, psychological, functional and social. There is a clear correlation between increasing severity of pain and greater interference with daily activities. Non-pain complications such as $\mathrm{HZ}$ ophthalmicus can increase the risk of permanent physical impairment. Some elderly individuals may experience a permanent loss of independence after an acute episode of $\mathrm{HZ}$. Current challenges in the management of $\mathrm{HZ}$ and $\mathrm{PHN}$ are highlighted, including the difficulty in administering antiviral agents before pain becomes established and the limited efficacy of pain treatments in many patients. We discuss the clinical rationale for the $\mathrm{HZ}$ vaccine and evidence demonstrating that the vaccine reduces the burden of the disease. The Shingles Prevention Study, conducted among $>38,000$ people aged $\geq 60$ years old, showed that the $\mathrm{HZ}$ vaccine significantly reduces the burden of illness and the incidence of both $\mathrm{HZ}$ and PHN. In the entire study population, zoster vaccination reduced the severity of interference of $\mathrm{HZ}$ and $\mathrm{PHN}$ with activities of daily living by two-thirds, as measured by two questionnaires specific to $\mathrm{HZ}$.
\end{abstract}

Summary: A vaccination scheme may positively impact the incidence and course of $\mathrm{HZ}$ disease, thereby improving patients' quality-of-life.

\section{Background}

Herpes zoster (HZ) is a common, painful and debilitating condition caused by a reactivation of the varicella-zoster virus (VZV) from a latent infection of sensory ganglia [13]. The disease course can be divided into four phases: prodrome, acute, subacute and chronic [4]. The prodrome occurs 1-5 days before the onset of $\mathrm{HZ}$ rash in $70 \%-80 \%$ of cases [5]. Symptoms are non-specific and range from itching to an intense burning sensation [6]. General constitutional symptoms (for example, fever, malaise, headaches) may also occur [5]. The acute phase of $\mathrm{HZ}$ disease is characterised by a vesicular skin rash in

* Correspondence: rwjbristol@doctors.org.uk

19 Ridgeway Road, Long Ashton, Bristol BS41 9EX, UK

Full list of author information is available at the end of the article the affected dermatome which is usually accompanied by acute pain [5,7]. Acute $\mathrm{HZ}$ is usually defined as occurring up to 30 days after rash onset [8]. In patients who subsequently develop chronic disease, there is a subacute phase (30-90 days after rash onset) [9].

Post-herpetic neuralgia (PHN) is the most common complication of HZ. A standard definition for PHN is lacking, but it is often defined as pain that persists for $\geq 90$ days after the onset of HZ rash [8]. The chronic pain of PHN is debilitating and can persist for months or years after the acute disease phase [10,11]. Studies vary in the reporting of the duration of persistent pain [12]. In one study of patients aged $\geq 65$ years, the mean duration of pain was 3.3 years, and ranged from 3 months to more than 10 years [13]. 
The lifetime risk of contracting $\mathrm{HZ}$ is one in four, but this risk increases markedly after 50 years of age due to an age-related decline in VZV-specific cell-mediated immunity $[6,14,15]$. PHN incidence also increases rapidly in individuals after the age of 60 years $[16,17]$. Of patients with $\mathrm{HZ}$ who are $\geq 50$ years old, as many as $10 \%-20 \%$ will develop PHN [11].

$\mathrm{HZ}$ is incorrectly perceived by many clinicians to be a mild and readily treatable disease. In fact, treatment options remain inadequate -- particularly for PHN -- and the disease can have devastating effects on patients' quality-of-life (QoL) in the acute and chronic phases $[13,18,19]$. These effects are widespread, affecting patients' physical and psychological health, as well as their ability to continue normal daily and social activities. Non-pain complications (for example, ophthalmic, neurological) are also a problem in patients with $\mathrm{HZ}$ [20].

This contribution discusses the available data on the impact of $\mathrm{HZ}$ and PHN on the QoL and functional status of patients and highlights the current challenges in their management. An increased awareness of the substantial burden of HZ and PHN on QoL is essential and may lead to an improvement in prevention and management strategies.

\section{Discussion}

The World Health Organization defines health as 'a state of complete physical, mental and social wellbeing, and not merely the absence of disease or infirmity' [21]. The term QoL, describes the overall sense of wellbeing that a person is experiencing, and how well that person can live a life that is normal for them [22]. Elements of QoL include basic activities (for example, managing to bathe, dress and eat), complex activities (for example, shopping and carrying out household chores), emotional wellbeing (for example, level of fear, anxiety, distress and ability to concentrate) and enjoying relationships with family, friends and social groups.

Clinical studies should assess all aspects of the life and health of a patient in order to establish how a disease or treatment affects their QoL [23]. Health-related QoL instruments measure four key health domains -- physical, psychological, social and functional (the latter includes the basic activities of daily living; ADL [18,23,24].

In patients with $\mathrm{HZ}$ and $\mathrm{PHN}$, the QoL analyses rely on subjective self-reporting using generic, standardized and validated health-status questionnaires such as EuroQoL and Short form (SF)-12 [19]. These generic tools are used to measure the impact of a disease on QoL consistently across the four domains of health in all types of patients and general populations [25]. The McGill Pain Questionnaire Present Pain Intensity (a generic tool for pain assessment) is also frequently used because pain is part of health status in the context of diseases such as $\mathrm{HZ}$ and PHN [19].

Two questionnaires have been specifically developed to assess how the pain and discomfort associated with $\mathrm{HZ}$ and PHN diminish functional capacity: the Zoster Brief Pain Inventory (ZBPI) [19,26] and the Zoster Impact Questionnaire (ZIQ) [19]. The ZBPI measures the impact of the pain and discomfort caused by $\mathrm{HZ}$ or PHN on the ability to carry out seven general activities: work, sleep, walking, life enjoyment, mood, relations with others and general activity $[19,26]$. This tool, therefore, determines the effect of $\mathrm{HZ}$ and PHN on QoL across all four domains of health. The ZIQ assesses how HZ pain and PHN affect the functional aspects of life (bathing, grooming, dressing, concentration, preparing meals, eating meals, housework, leisure activities, leaving the house, shopping, travelling). The ZIQ is more focused on daily activities than the ZBPI [19]. The ZBPI has been evaluated against other validated pain questionnaires, but the ZIQ has not [19]. Both of these tools are recognized as sensitive and reliable measures of the impact of $\mathrm{HZ}$ and $\mathrm{PHN}$ on patients' daily lives $[19,27]$.

\section{Impact of HZ-related pain on QoL and ADL}

Pain is usually the predominant symptom in all phases of HZ disease, being reported by up to $90 \%$ of patients [28]. The intensity of pain in patients with $\mathrm{HZ}$ and PHN is assessed using subjective self-reporting. Patients are asked to rate their level of $\mathrm{HZ} / \mathrm{PHN}$ pain (for on average or at its worst) on a numerical rating scale from 0 (no pain) to 10 (pain as bad as you can imagine).

\section{Features of $\mathrm{HZ}$ pain}

Most patients with acute $\mathrm{HZ}$ experience moderate or severe dermatomal pain in the skin innervated by the afflicted ganglion [11]. Acute-phase pain is due to the damage to neuronal tissues as a result of viral replication and immune responses [1,29]. Patients rank pain during the acute phase as more intense than post-surgical or labour pain [30].

Pain in the acute phase can be constant or intermittent and may show varied symptoms, such as burning or stabbing sensations, itching, tingling or numbness, anginalike aching or squeezing sensations and a deep aching or 'pulled muscle' sensation [10]. Many patients present with tactile allodynia (pain from a stimulus that is not normally painful) such as the touch of clothing or a light breeze across the skin [10]. Allodynia can be very disabling and may predict a higher risk of developing PHN [9]. Other PHN predictive factors include the presence of prodromal pain, severity of rash, severity of pain and ophthalmic localization [31-35].

\section{Impact of $\mathrm{HZ}$ pain on Qol}

The substantial impact of acute-phase pain on QoL is being increasingly recognized, with QoL studies showing 
effects on patients' lives across all four health domains (Table 1) $[18,19,24,26,36-38]$. Many patients report that pain during the acute phase of $\mathrm{HZ}$ impacts 'quite a bit' or 'extremely' on their physical, role and social functioning [18]. Depression is also reported by patients with acute symptoms of HZ [18]. In a study of 50 patients with acute-phase HZ aged 54-94 years, a clear correlation between increased pain intensity and greater interference with activities (including general activity, work, sleep and enjoyment of life) was observed (Figure 1) [36]. At a moderate pain level of 4, 20\%-30\% reported interference but, at a high pain level of 9 or $10, \geq 66 \%$ reported an effect on each activity.

Different components of acute-phase pain impact on different health domains. This has been demonstrated by multivariate analyses, controlling for patients' demographic and clinical variables [18]. Data showed that significant independent contributions were made by sensory components of pain to poor physical functioning, affective components of pain to depression and psychological impairment and overall pain burden (sensory and affective combined) to poor social and role functioning.

Some elderly individuals may experience a permanent loss of independence, never fully regaining their lifestyles, interests and levels of activity after an acute episode of HZ [24].

\section{Clinical features of PHN}

PHN is characterized by constant and/or intermittent paroxysmal pain persisting for $\geq 90$ days after the onset of $\mathrm{HZ}$ rash $[8,10]$. For some patients, PHN is a continuation

\section{Table 1: Impact of herpes zoster and post-herpetic neuralgia on all four health domains}

\begin{tabular}{ll}
\hline Physical & Psychological \\
\hline Fatigue & Depression \\
Anorexia & Anxiety \\
Weight loss & Emotional distress \\
Reduced mobility & Difficulty concentrating \\
Physical inactivity & Fear \\
Insomnia & \\
\hline Social & Functional \\
\hline Withdrawal & Dressing, bathing, eating, \\
Isolation & mobility \\
Attendance at fewer social & Travelling, cooking, \\
gatherings & housework, shopping \\
Coss of independence & \\
\hline
\end{tabular}

of the painful symptoms of the acute phase of HZ; others experience completely different pains and sensations. Allodynia is present in $\geq 70 \%$ of patients and is usually considered to be the most distressing and debilitating PHN component $[10,28]$. Numbness and tingling also contribute to the PHN burden [10]. Clinically, there is an area of scarred skin, which denotes sensory loss and the wider area of dynamic mechanical allodynia. Other neuropathic features include burning, electric shocks, pins and needles and itching. The 'neuropathic itch' in PHN patients may lead to injury in those who scratch itchy skin so much that loses its protective sensation [39].

Most patients categorise the intensity of PHN as moderate-to-severe (pain scores $\geq 4$ on a scale of 0 -10) despite receiving analgesic agents [40]. The persistency of PHN means that patients have few periods of respite from erratic, painful and prolonged attacks.

\section{Impact of PHN on Qol}

Reduced QoL is a particular problem in patients whose pain persists as PHN. The impact of PHN on patients lives is substantial and apparent across all domains of QoL (Table 1, Figure 2) [13,19,37,38,40-42]. There is a positive correlation between increasing pain severity and the extent of the negative impact on QoL [13]. In a study that assessed the impact of pain, medication use and QoL in 385 patients with PHN aged $>65$ years, $40 \%$ of respondents said that pain moderately to severely affected their ability to carry out general activities (Figure 2) [13]. In addition, $48 \%$ of patients commented that pain interfered moderately or severely with their enjoyment of life (Figure 2) [13].

PHN causes a loss of physical function, with patients experiencing fatigue, anorexia, weight loss, reduced mobility, physical inactivity, sleep disturbance (especially insomnia) and reductions in overall health $[8,13]$. PHN makes undertaking basic tasks (for example, bathing, dressing, eating) and complex activities (for example, travelling, performing household chores, shopping) difficult [8]. Institutionalization and a loss of autonomy can occur in elderly patients with PHN [24]. The loss of social contact, withdrawal and isolation can occur in patients with PHN because they experience reduced independence and participate less in social gatherings $[8,24]$.

PHN may also affect patients' psychological wellbeing $[13,34]$. Psychosocial scores improve in patients who fully recover from the acute symptoms of $\mathrm{HZ}$, but they remain low in patients who develop PHN [34]. Patients with intense pain are at greater risk of anxiety and depression than those who report milder pain $[8,13]$. Patients with PHN report difficulty in concentrating [24]. They also fear recurrences of PHN symptoms and may experience changes in their emotional roles within key relationships. A substantial proportion of patients receive medication for depression, anxiety and sleep disturbances related to 


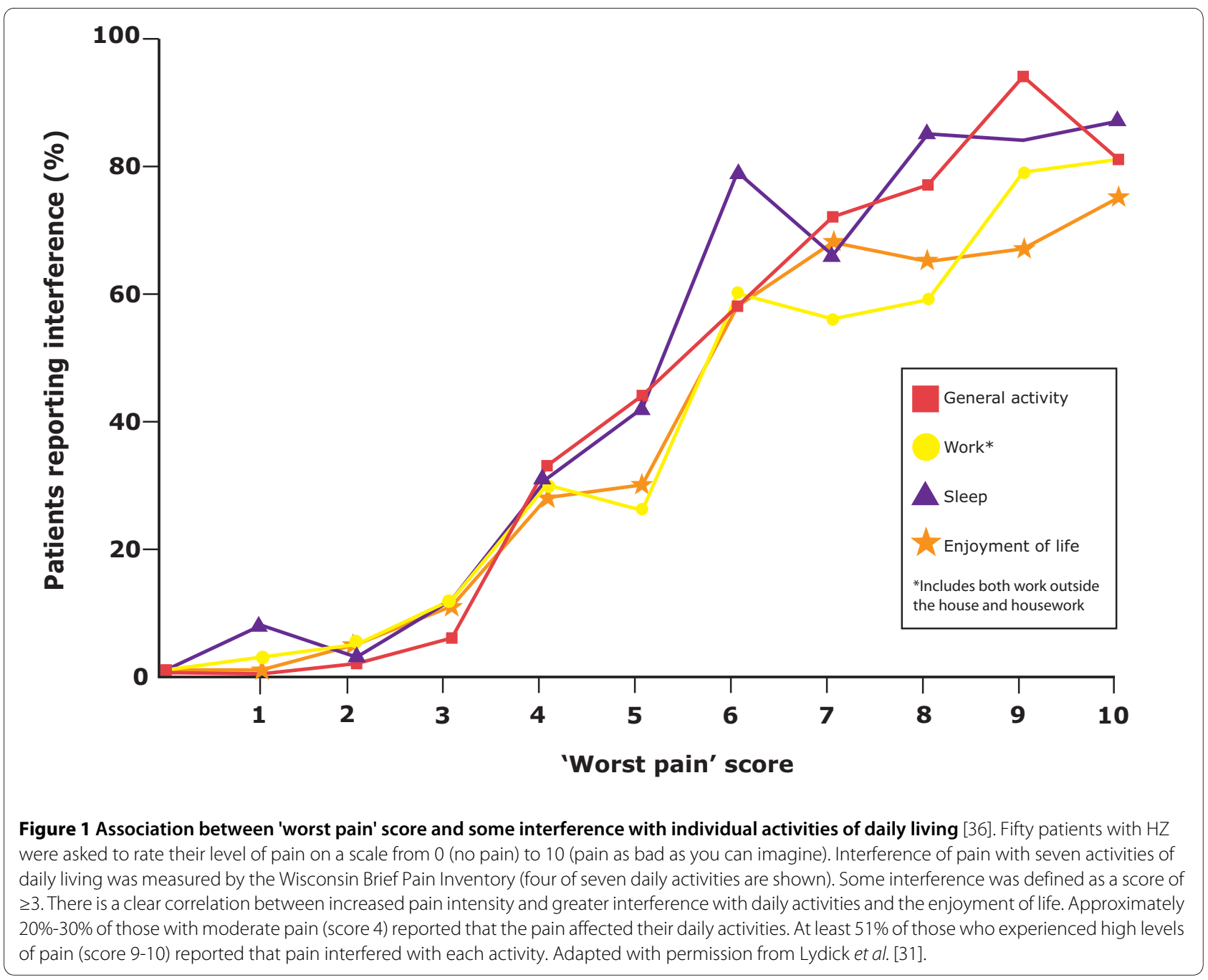

PHN [40]. Some patients became suicidal as a direct consequence of PHN [38].

\section{Non-pain symptoms and complications of $\mathrm{HZ}$ may also affect QoL}

Several typical symptoms of $\mathrm{HZ}$ can be debilitating for patients, even among those who do not experience clinically meaningful pain [43]. The main characteristic of the acute phase of $\mathrm{HZ}$ is the rash which, together with subsequent scarring, may be unsightly [28].

$\mathrm{HZ}$ can also give rise to non-pain complications, many of which can increase the risk of permanent or longstanding physical impairment [20]. Complications can be ophthalmic (for example, herpes zoster ophthalmicus), neurological (for example, cranial and peripheral nerve palsies), dermatological (for example, bacterial superinfection) or visceral (for example, pneumonia; Table 2) [20]. A degree of motor deficit is common in patients with HZ; severe and long-lasting paresis may rarely occur if $\mathrm{HZ}$ affects the cervical and lumbosacral dermatomes [44]. HZ patients may also be at greater risk of stroke.
Two recent retrospective population-based studies in Taiwan found that $\mathrm{HZ}$ and herpes zoster ophthalmicus patients had a 1.31-fold and 4.52-fold higher risk of stroke, respectively, in the following year $[45,46]$. Almost one in 10 immunocompetent patients with $\mathrm{HZ}$ is affected by at least one non-pain complication [47]. The incidence of complications becomes more common with increasing age: patients aged $>65$ years have four-times the number of complications than do individuals younger than 35 years [48].

Complications associated with $\mathrm{HZ}$ and PHN place a heavy burden on individuals, who may suffer a permanent reduction in QoL even if the original HZ symptoms fully resolve [24].

\section{Wider impact of $\mathrm{HZ}$ and $\mathrm{PHN}$ on QoL}

A survey by Weinke $e t$ al. was designed to capture the full course of $\mathrm{HZ}$ episodes from rash onset to pain resolution. The findings demonstrate the major and wide-ranging impact that HZ, and in particular PHN, have on patients' QoL [49]. Eleven thousand interviews were conducted in 


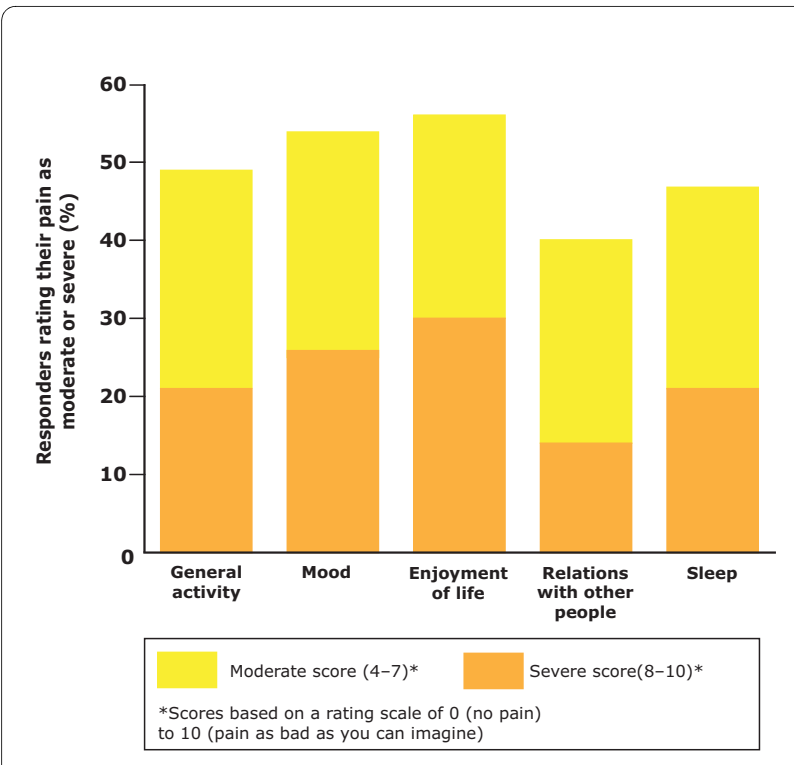

Figure 2 Impact of post-herpetic neuralgia (PHN) across different aspects of quality-of-life (QoL) [13]. A study assessed the impact of pain, medication use and QoL in 385 patients with PHN aged $>65$ years. Pain causes disruption across many aspects of life for PHN patients. As many as $40 \%$ of respondents said that pain moderately or severely affected their ability to carry out general activities. Forty-eight percent of patients commented that pain interfered moderately or severely with their enjoyment of life. Adapted with permission from Oster et al. [13].

Germany to evaluate patient-rated pain in historic $\mathrm{HZ}$ episodes and interference with ADL. Screening questions identified 280 patients $\geq 50$ years old with painful $\mathrm{HZ}$ diagnosed during the previous 5 years, of whom 32 patients developed PHN. Patients with PHN scored significantly worse across all outcomes related to pain and QoL than those with HZ [49]. The mean interference of pain on different aspects of QoL was highest for sleep, mood and work [49]. Three-quarters of patients experienced problems in carrying out daily activities, including work, studies, housework, family and leisure activities [49]. Approximately $60 \%$ of employed interviewees had to stop work at some point during the active disease period [49].

When patients' partners were asked how $\mathrm{HZ}$ or PHN had affected patients' QoL, most replied that the symptoms interfered considerably with patients' ADL. This was particularly evident for people who developed PHN [50]. Not only patients are affected by this disease: caring for patients with chronic diseases places a burden on their partners' personal lives and finances [51]. Patients' partners and family members may need to fill additional roles. Caring for a person with $\mathrm{HZ}$ or PHN may cause family members to take time off work [52]. Patients and their partners are less likely to attend or participate in social occasions $[24,51]$.
Table 2: The four main domains of complications (excluding post-herpetic neuralgia) identified in patients with acute herpes zoster (HZ)

\begin{tabular}{|c|c|}
\hline Domain & Complications \\
\hline \multirow[t]{8}{*}{ Neurological [20] } & Vertigo \\
\hline & $\begin{array}{l}\text { Cranial nerve palsies (for example, } \\
\text { facial paresis) }\end{array}$ \\
\hline & Hearing loss \\
\hline & Varicella zoster virus encephalitis \\
\hline & Motor neuropathy \\
\hline & Myelitis \\
\hline & Small-vessel encephalitis \\
\hline & $\begin{array}{l}\text { Granulomatous arteritis with } \\
\text { secondary stroke }\end{array}$ \\
\hline \multirow[t]{8}{*}{ Ophthalmic [74] } & Ptosis \\
\hline & Scleritis \\
\hline & Iridocyclitis \\
\hline & Secondary glaucoma \\
\hline & Cataract \\
\hline & Keratitis \\
\hline & Blindness \\
\hline & Chorioretinitis \\
\hline \multirow[t]{3}{*}{ Dermatological [20] } & Disseminated $\mathrm{HZ}$ \\
\hline & Post-herpetic (persisting) pruritus \\
\hline & $\begin{array}{l}\text { Secondary bacterial skin infections } \\
\text { (with subsequent scarring, cellulitis, } \\
\text { septicaemia) }\end{array}$ \\
\hline \multirow[t]{6}{*}{ Visceral [20] } & Pneumonia \\
\hline & Peri-myocarditis \\
\hline & Hepatitis \\
\hline & Oesophagitis \\
\hline & Myositis \\
\hline & Arthritis \\
\hline
\end{tabular}

HZ-related hospitalizations may contribute to the burden of HZ and PHN on patients and their families [53]. It is estimated that, in Europe, approximately 12,000 hospitalizations each year are due to $\mathrm{HZ}$ and its complications [38,48,54-56]. HZ complications which are likely to lead to hospitalization are PHN, encephalitis or meningitis and ocular complications [57]. Of 88,650 estimated annual cases of $\mathrm{HZ}$ in individuals $\geq 60$ years old in England and Wales, an estimated $1750(2 \%)$ hospitalizations are due primarily to HZ [53]. In Connecticut, USA, the mean annual hospitalization rate due to principal or secondary diagnosis of $\mathrm{HZ}$ over a 10-year period is 16.1/ 
Table 3: Quality-of-life (QoL) scores obtained from patients with herpes zoster (HZ) compared with different chronic diseases

\begin{tabular}{|c|c|c|c|c|c|c|}
\hline SF-36 domain & $\begin{array}{l}\text { Within two weeks } \\
\text { of } \mathrm{HZ} \text { onset }(n=46)\end{array}$ & $\begin{array}{l}\text { Hyper-tension } \\
(n=2089)\end{array}$ & $\begin{array}{l}\text { Congestive heart } \\
\text { failure }(n=216)\end{array}$ & $\begin{array}{l}\text { Diabetes } \\
\text { mellitus ( } n=541)\end{array}$ & $\begin{array}{l}\text { Myocardial infarction } \\
(n=107)\end{array}$ & Depression $(n=502)$ \\
\hline General health & 71 & 63 & 47 & 56 & 59 & 53 \\
\hline Vitality & 45 & 58 & 44 & 56 & 58 & 40 \\
\hline Body pain & 35 & 72 & 63 & 69 & 73 & 59 \\
\hline Mental health & 67 & 78 & 75 & 77 & 76 & 46 \\
\hline $\begin{array}{l}\text { Role limitations due to emotional } \\
\text { problems }\end{array}$ & 48 & 77 & 64 & 76 & 73 & 39 \\
\hline Physical functioning & 63 & 73 & 48 & 68 & 69 & 72 \\
\hline $\begin{array}{l}\text { Role limitations due to physical } \\
\text { problems }\end{array}$ & 19 & 62 & 34 & 57 & 51 & 44 \\
\hline Social functioning & 52 & 87 & 71 & 82 & 85 & 57 \\
\hline
\end{tabular}

Modified from [31] and [59].

All scores were calculated using Short Form (SF)-36, a well-validated tool for measuring QoL that has a maximum score of 100; scores under 50 (in bold) represent low QoL 
100,000 (range, 14.5-18.2) [58]. Almost 67\% of these patients were aged $>64$ years.

\section{Comparisons between $\mathrm{HZ}$ or PHN and chronic conditions}

The impact of acute HZ disease on patients' QoL is considerable [36], equalling that seen with common debilitating chronic conditions such as congestive heart failure, diabetes mellitus, myocardial infarction and clinical depression [59] (Table 3). HZ patients have an extremely low score for role limitations due to physical problems (scoring 19 out of 100, Table 3). They cannot accomplish daily duties or fulfil their roles as well as they would normally expect because of the acute effects of HZ. In patients with PHN, pain ranks very high compared with pain from other chronic conditions such as atypical facial pain, osteoarthritis and rheumatoid arthritis [30].

QoL analysis has been undertaken using data from a general-population group (including healthy people and those with a wide range of chronic conditions such as arthritis, chronic lung disease, congestive heart failure, diabetes, myocardial infarction or angina and hypertension; Leplège, unpublished data). Compared with the mean QoL level for each domain in the general population, patients suffering from HZ have poorer QoL scores (Figure 3) [38]. During the acute phase of HZ, the impact is clinically meaningful for some domains. For patients suffering from complications or PHN, the impact is higher and all the domains are affected (Figure 3) [38].

\section{Current challenges in the treatment of $\mathrm{HZ}$ and PHN}

Treatment of patients with $\mathrm{HZ}$ aims to accelerate rash healing, relieve pain and reduce complications [5]. Current treatments are effective in some patients, but therapies may show limited efficacy and poor tolerability in others (particularly in the elderly; Table 4).

Despite the development of treatment guidelines by the International Herpes Management Forum [60], HZ management is complex [61]. The guidelines recommend oral antiviral agents for 7 days in patients with $\mathrm{HZ}$ who are at risk of developing PHN (patients aged $>50$ years with

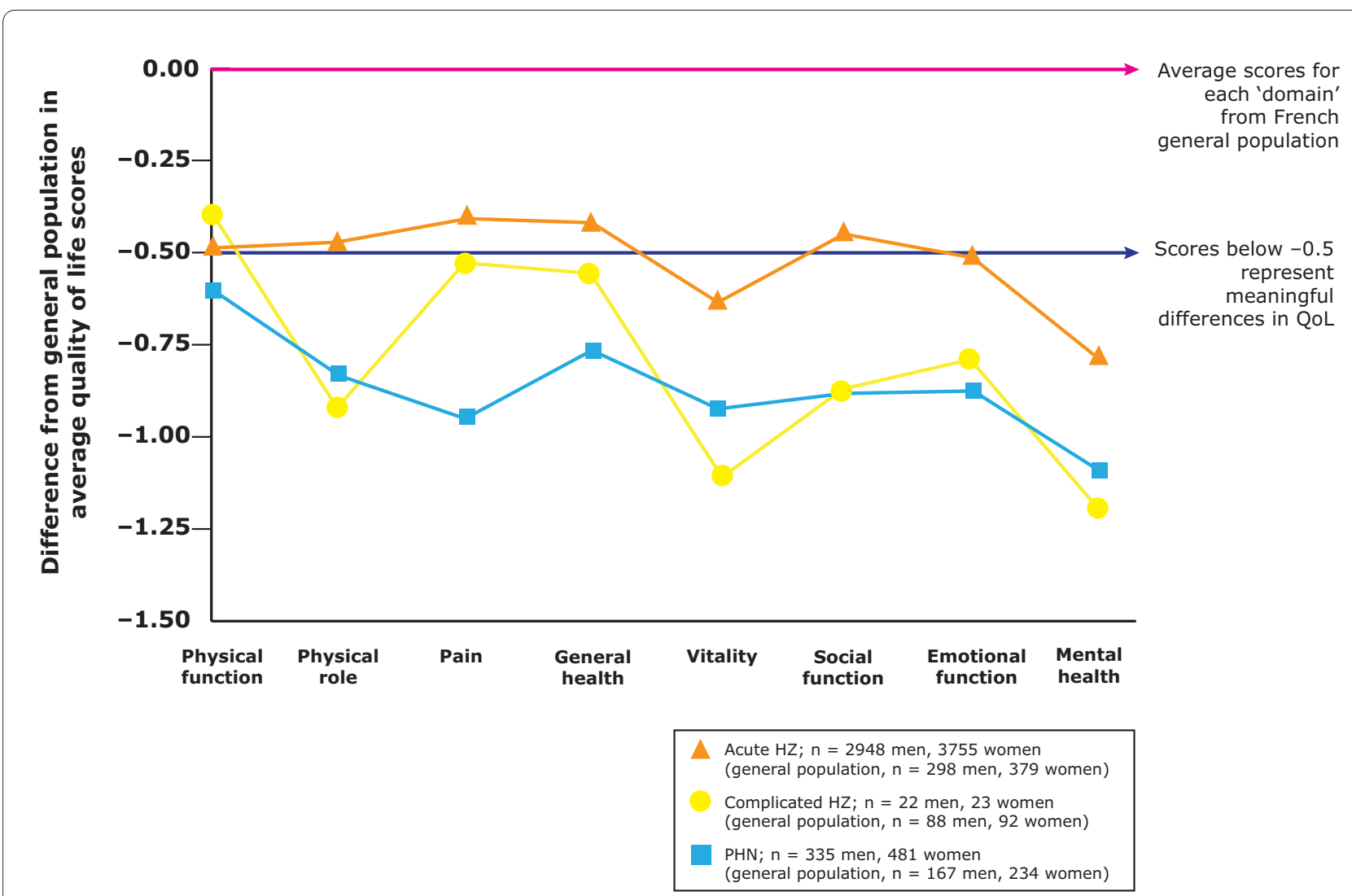

Figure 3 Quality-of-life (QoL) scores in a French general population cohort versus patients with herpes zoster (HZ) or post-herpetic neuralgia (PHN) (Leplège, unpublished data; adapted from Figure 2 in Chidiac 2001 [38]). The French general population cohort comprised healthy individuals and individuals with various chronic diseases $(n=3656)$. Average Short-Form-36 (SF-36) scores (eight domains) were calculated for the general French population and for patients with acute $\mathrm{HZ}$, HZ-related complications, and PHN. The differences in scores between each patient group and the general French population are presented. Patients with $\mathrm{HZ}$ and PHN have poorer QoL scores than the general-population group. Clinically meaningful differences (scores below -0.5) are observed for some domains in patients with $\mathrm{HZ}$, and for all domains in patients with complicated $\mathrm{HZ}$ or PHN. All three groups of patients scored low for the SF-36 domains of vitality and mental health. 
Table 4: Effect on pain and quality-of-life of agents used to treat herpes zoster (HZ) and/or post-herpetic neuralgia (PHN)

\begin{tabular}{|c|c|c|}
\hline Treatment & Advantages & Disadvantages \\
\hline Antiviral agents & $\begin{array}{l}\text { Relieve acute } \mathrm{HZ} \text { pain and accelerate lesion healing } \\
\text { if administered within } 72 \mathrm{~h} \text { of acute-symptom } \\
\text { onset }[8] \text {. } \\
\text { Few adverse effects }[75,76] \text {. } \\
\text { May slightly reduce } \mathrm{PHN} \text { symptoms and their } \\
\text { duration }[5,8,60,67,71,77-79] \text {. }\end{array}$ & $\begin{array}{l}\text { Administration within } 72 \mathrm{~h} \text { is usually not achievable } \\
\text { [8]. } \\
\text { In clinical trials, } 20 \%-30 \% \text { of treated patients still } \\
\text { develop PHN }[37,71] .\end{array}$ \\
\hline Corticosteroids & $\begin{array}{l}\text { Reduce intensity of pain and overall duration of the } \\
\text { acute phase }[37,80,81] \text {. } \\
\text { Significantly accelerate time to uninterrupted } \\
\text { sleep, return to daily activity, and cessation of } \\
\text { analgesic therapy. }\end{array}$ & $\begin{array}{l}\text { Do not prevent PHN and produce significant } \\
\text { adverse events in older adults; their routine use is } \\
\text { therefore not recommended in elderly patients } \\
\text { with } \mathrm{HZ} \text { [37]. }\end{array}$ \\
\hline Simple analgesics & May reduce pain in $\mathrm{HZ}$ and $\mathrm{PHN}[11,75]$. & Few trials assessing efficacy in $\mathrm{HZ}$ or $\mathrm{PHN}$. \\
\hline Tricyclic antidepressants & $\begin{array}{l}\text { Provide effective pain relief in PHN patients } \\
\text { (numbers needed to treat }=2.8 \text { ) and may possibly } \\
\text { provide benefits through sedative actions given } \\
\text { that PHN can induce sleep disturbances and } \\
\text { anxiety [67]. }\end{array}$ & $\begin{array}{l}\text { Side-effects may cause further QoL problems. } \\
\text { Patients do not regain the level of life-satisfaction } \\
\text { that they had before PHN developed }[43,67] \text {. }\end{array}$ \\
\hline Antiepileptics & $\begin{array}{l}\text { Gabapentin and pregabalin offer reasonable relief } \\
\text { for PHN [82-84]. }\end{array}$ & $\begin{array}{l}\text { Levels of pain relief are not associated with similar } \\
\text { improvements in QoL scores [82-84]. }\end{array}$ \\
\hline Opioids & $\begin{array}{l}\text { Maximum tolerable doses may reduce } \mathrm{PHN} \text { pain } \\
\text { [67]. }\end{array}$ & $\begin{array}{l}\text { Side-effects are common and troublesome, } \\
\text { particularly for elderly patients; overall benefits are } \\
\text { therefore limited [67]. }\end{array}$ \\
\hline Topical agents & $\begin{array}{l}\text { Lidocaine patch provides some pain relief and has } \\
\text { few side-effects [85]. } \\
\text { Capsaicin dermal patch significantly reduces pain } \\
\text { [86]. }\end{array}$ & $\begin{array}{l}\text { Discomfort experienced with capsaicin } \\
\text { formulations; overall benefits are therefore limited } \\
\text { [11]. } \\
\text { Pain relief with capsaicin dermal patch is not } \\
\text { associated with improved QoL in PHN [86]. }\end{array}$ \\
\hline $\begin{array}{l}\text { Epidural therapies and } \\
\text { nerve blocks }\end{array}$ & $\begin{array}{l}\text { Continuous epidural local anaesthetic has been } \\
\text { shown to effectively treat acute-phase HZ pain [87]. } \\
\text { Prolonged (not single-dose or short-term) epidural } \\
\text { local anaesthetic blockade with corticosteroid may } \\
\text { provide some protection against PHN [88]. }\end{array}$ & $\begin{array}{l}\text { Single-dose epidural local anaesthetic/steroid does } \\
\text { not prevent PHN [89]. } \\
\text { Epidural corticosteroid has potential risk, and } \\
\text { anecdotal evidence has not supported the benefit. } \\
\text { Prolonged epidural local anaesthetic blockade is } \\
\text { not practical for widespread use and carries some } \\
\text { risk [88]. }\end{array}$ \\
\hline
\end{tabular}

severe acute pain, severe rash, or significant prodromal symptoms) [60]. Studies have shown that aciclovir, valaciclovir and famciclovir decrease viral shedding, relieve acute phase pain, reduce the formation of new lesions and accelerate healing $[5,62,63]$. In general, these treatments are well tolerated, even by older patients [37]. By reducing viral replication, they may decrease the duration of acute-phase pain and PHN $[4,5]$.

To be effective, antiviral agents must be administered within $72 \mathrm{~h}$ of acute-symptom onset [60], which may be difficult because of delays in patients seeking medical advice and delays in reaching diagnosis (for example, due to presentation of unusual symptoms) [8]. Often, viral activity and neuronal damage have been ongoing for several days before appropriate treatment is given [4]. Even with prompt treatment, antiviral treatment does not prevent all cases of PHN [37,64]. A recent Cochrane Review demonstrated that oral acyclovir does not significantly reduce PHN incidence [64]. The Cochrane review highlighted that there is insufficient evidence from randomized controlled trials to determine if other antiviral agents prevent PHN and if these treatments have a beneficial 
impact on QoL [64]. Twenty studies of antiviral treatment for acute $\mathrm{HZ}$ were identified, but 14 were excluded from the Cochrane review, mainly because of limitations with the study design.

A recent Canadian study of patients with $\mathrm{HZ}$ rash or pain showed that pain resolution is associated with recovery of QoL to a pre-morbid state (personal communication). Data showed that the median duration of pain was equal to the median duration of QoL impairment. Once established, the pain associated with $\mathrm{HZ}$ or PHN is difficult to treat [65]. PHN remains largely refractory to pharmacological treatments and prevention strategies [66]. Data show that $>50 \%$ of patients require more than one prescription drug for PHN [13]. Despite treatment, symptomatic relief is obtained in only $50 \%$ of patients [67]. Patients with PHN experience significantly less pain relief than those with $\mathrm{HZ}$, despite receiving more pain medications (mean, 2.2 versus 1.6) [49]. Studies have assessed the 'number needed to treat' for existing PHN therapies (how many patients need to be treated $\mathrm{n}$ order to achieve at least $50 \%$ pain relief in one patient compared with the controls). Data highlight the limited pain relief obtained in PHN patients. For some standard treatments, approximately four patients with PHN need to be treated in order to achieve pain relief in one patient (Figure 4) [68].

As patients with PHN may find it difficult to tolerate pain therapies, drug doses are often titrated. This may result in several weeks of suboptimal treatment, during which it is unclear if (or when) the drugs will become effective [67]. Therapeutic compliance is also difficult to achieve. Almost $50 \%$ of patients with PHN do not discuss their symptoms regularly with physicians [13]. One in 10 is troubled substantially by the side-effects of PHN treatments $[13,24]$.

Treatment dissatisfaction is high in patients with PHN. In one study, only $14 \%$ of patients aged $>65$ years were satisfied with pain medication for PHN [13]. In the survey by Weinke et al. [49], patient-reported satisfaction with $\mathrm{HZ}$ treatments was significantly lower in patients with PHN versus those with HZ (6.8 versus 8.3; scale from 0 , 'not satisfied' to 10 , 'very satisfied').

\section{Vaccination may reduce the burden of $\mathrm{HZ}$ disease}

Current treatment strategies for $\mathrm{HZ}$ and $\mathrm{PHN}$ are only partially effective, so reducing the burden of $\mathrm{HZ}$ disease remains an area of considerable need [11]. A solution is for proactive strategies to focus on $\mathrm{HZ}$ prevention [67]. At least one study has shown that, compared with people who have not experienced HZ, those who have had HZ or PHN place higher value on preventing this disease. In this study, both groups questioned (community members and patients with $\mathrm{HZ}$ or PHN) said that they would be willing to pay substantial amounts of money to prevent HZ [69].

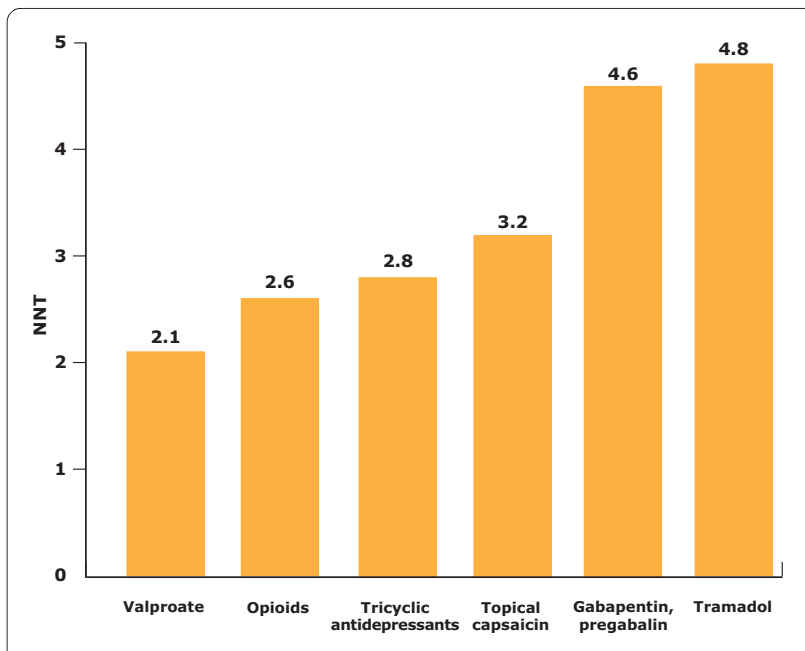

Figure 4 Number needed to treat with common pain therapies to obtain $50 \%$ pain relief in one patient [68]. Data highlight the limited relief from pain obtained in patients with post-herpetic neuralgia (PHN). For some treatments, approximately four patients with PHN need to be treated to achieve 50\% pain relief in one patient.

The clinical rationale for the development of an $\mathrm{HZ}$ vaccine has centred on reducing the severity of $\mathrm{HZ}$ and PHN. Studies have shown that the live attenuated Oka/ Merck VZV vaccine ('zoster vaccine') also reduced the incidence of $\mathrm{HZ}$ and PHN in addition to burden of illness (a severity-by-duration measure of the total pain and discomfort associated with a disease). Evidence that the zoster vaccine reduces $\mathrm{HZ}$ burden in an ageing population is derived from the Shingles Prevention Study [70]. The Shingles Prevention Study had a randomized, double-blind, placebo-controlled design and assessed $\mathrm{HZ}$ burden of illness and PHN incidence (pain rated as $\geq 3$ on a $0-10$ scale $\geq 90$ days after rash onset) in $>38,000$ people aged $\geq 60$ years who received zoster vaccine or placebo. Compared with placebo, vaccination significantly reduced $\mathrm{HZ}$ burden of illness by $61.1 \%$. Vaccine recipients had a significantly reduced incidence of $\mathrm{HZ}(-51 \%)$ and PHN (-67\%) compared with placebo [70,71]. HZ symptoms in the vaccine group were, in general, milder and of shorter duration than those in the placebo group $[70,71]$. Vaccination reduced PHN incidence defined using alternative cut-off times for the duration (persistence) of pain; the reduction in incidence was $72.9 \%$ at 180 days (Figure 5) [70,71]. Although the reduction in HZ incidence with vaccine compared with placebo was less apparent in patients who were aged $\geq 70$ years versus those aged 60-69 years, the reductions in HZ burden of illness and PHN were preserved in the older population [70].

In an adverse event substudy of the Shingles Prevention Study, rates of serious adverse events were higher in the vaccine group (1.9\%) than in the placebo group (1.3\%) [70]. Injection site reactions were more frequent among 
vaccine recipients than those taking placebo (48.3\% versus $16.6 \%$, respectively), but were generally mild.

The impact of vaccination on QoL was assessed in the entire study population of the Shingles Prevention Study using ZBPI and ZIQ questionnaires. Mean ZBPI and ZIQ scores, which rated the 'interference' of $\mathrm{HZ}$ and PHN with $\mathrm{ADL}$, were used to calculate a 'severity of interference score'. For the entire study population, zoster vaccination reduced the ZBPI severity of interference by $66 \%$ (95\% confidence interval; CI: 55,74$)$ and the ZIQ severity of interference by $68 \%$ ( $95 \%$ CI: 57,77 ). In individuals who developed HZ, vaccination reduced the ZBPI severity of interference by $31 \%(95 \%$ CI: 12,51$)$ and the ZIQ severity of interference by $35 \%$ ( $95 \%$ CI: 13, 57). Zoster vaccination therefore reduced the burden of HZ-related interference with ADL by about two-thirds in a population of older adults and by about one-third in vaccine recipients who developed disease [72]. Much of the effectiveness of the zoster vaccination was due to the prevention of $\mathrm{HZ}$ episodes [70-73].

\section{Summary}

$\mathrm{HZ}$ is a common disease that can substantially reduce patients' QoL and functional status. HZ is rare in young individuals, but there is a marked increase in risk after 50 years of age. The consequences of $\mathrm{HZ}$ are a particular problem in older individuals. In part, this may be due to slow healing of nerve damage and inflammatory scarring in an ageing nervous system. The number of cases of $\mathrm{HZ}$ and $\mathrm{PHN}$ is expected to increase in coming decades due to the steady rise in the mean age of the population.

Pain is the major symptom that affects the QoL and $\mathrm{ADL}$ of patients and is usually present across all phases of $\mathrm{HZ}$ disease. In patients whose pain persists for months or

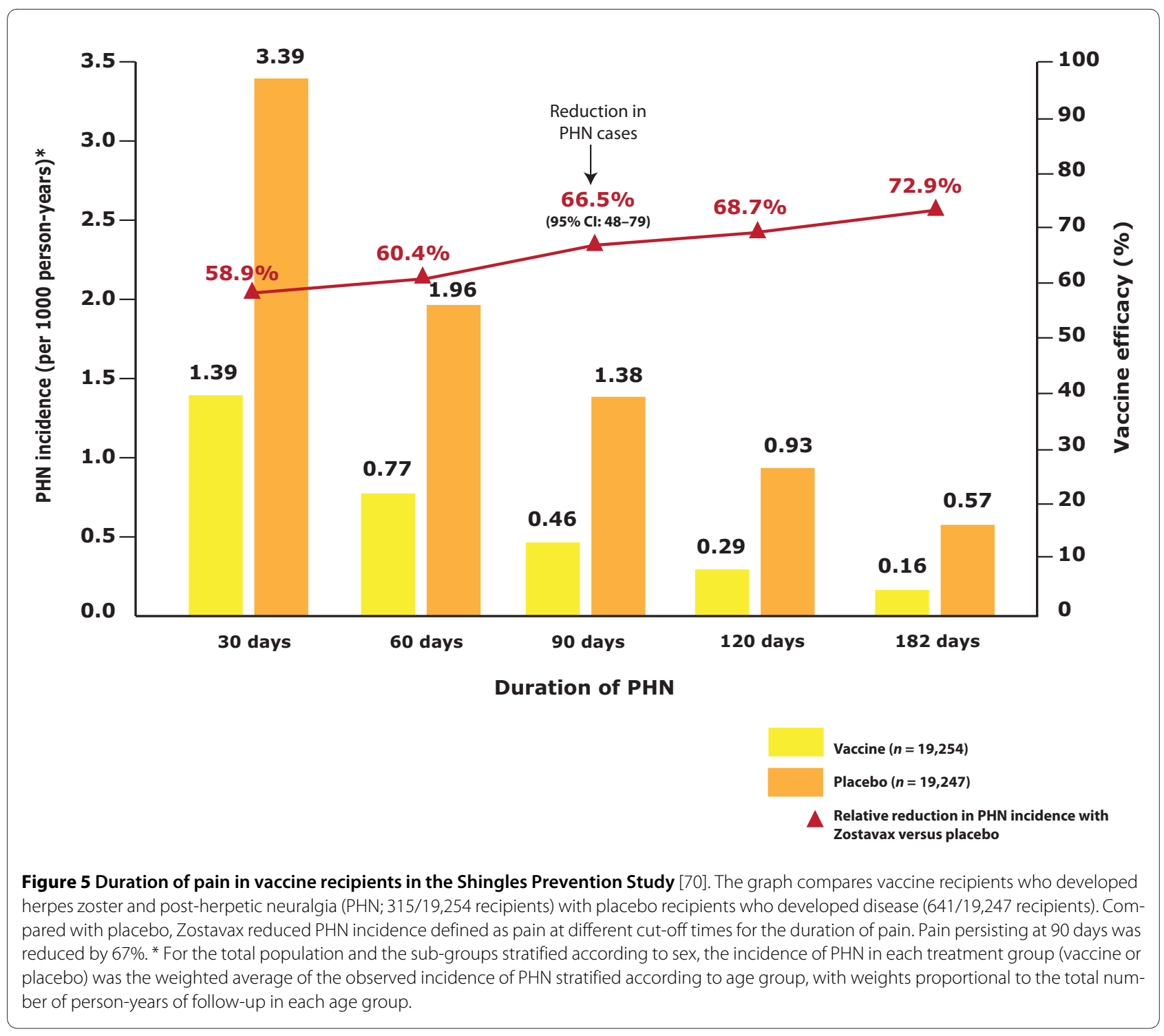


years as PHN, the effects on patients' lives can be devastating. The negative effects of $\mathrm{HZ}$ and PHN on physical, social, functional and psychological health are as substantial as the effects described by patients with other chronic health conditions. Non-pain-related complications of $\mathrm{HZ}$ may also contribute to a reduced QoL. HZ and PHN can also have significant consequences for patients' partners, relatives and social circle.

To be effective, antiviral medication needs to be started within $72 \mathrm{~h}$ of the onset of acute symptoms. Antiviral agents show limited efficacy if administered within $72 \mathrm{~h}$ of acute-symptom onset. Treatment within this time is often not achievable and patients may present with pain that is established and difficult to treat. Current treatments for PHN are largely suboptimal and often accompanied by intolerable side-effects. Awareness of these challenges and the substantial burden of $\mathrm{HZ}$ and PHN on patients' QoL may lead to improved prevention and management strategies.

Zoster vaccine has been demonstrated to attenuate the severity of $\mathrm{HZ}$ disease and significantly reduce the incidence of $\mathrm{HZ}$ and PHN. The introduction of a prophylactic vaccination scheme may achieve a significant positive impact on the incidence and course of $\mathrm{HZ}$ disease, thereby improving patients' QoL.

\section{Abbreviations \\ ADL: activities of daily living; Cl: confidence interval; $\mathrm{HZ}$ : herpes zoster; PHN: post-herpetic neuralgia; QoL: quality-of-life; VZV: varicella-zoster virus; ZBPI: Zoster Brief Pain Inventory; ZIQ: Zoster Impact Questionnaire. \\ Competing interests \\ RWJ received honoraria as consultant and/or lecturer for Merck, Sanofi Pasteur MSD, Novartis, Astellas, GSK and Merck Frosst. DB received support from Sanofi Pasteur MSD, Sanofi Aventis, Pfizer, Boehringer Ingelheim, Eli Lilly. GK received an honoraria and support to attend scientific meetings from Sanofi Pasteur MSD, GSK, Novartis, AstraZeneca, Sanofi Aventis, Pfizer and Roche. AL was a consultant for Sanofi Pasteur MSD. KES received a grant support from Merck and Wyeth and was a consultant for Merck and GSK. TW received honoraria as a consultant and/or lecturer for GSK, Novartis Vaccines and Sanofi Pasteur MSD.}

\section{Authors' contributions}

All authors contributed to the content of this manuscript and have read and approved the final draft.

\section{Acknowledgements}

The authors take full responsibility for the content of this contribution but thank Communigen Limited Oxford, UK (supported by Sanofi Pasteur MSD) for their assistance in preparing the manuscript.

\footnotetext{
Author Details

19 Ridgeway Road, Long Ashton, Bristol BS41 9EX, UK, 2INSERM U987, Hôpital Ambroise Paré, APHP, F-92100 Boulogne-Billancourt, France, ${ }^{361}$ Plough Lane, Wokingham, Berkshire, RG40 1RQ, UK, 4Université Paris Diderot, Département Histoire et Philosophie des sciences, Bâtiment les Grands Moulins - Case 7019, 75205 Paris cedex 13, France, ${ }^{5}$ Durham Veterans Administration, Medical Center (VAMC), Division of Geriatrics, DUMC 3469, Durham, NC 27710, USA and ${ }^{6}$ linikum Ernst von Bergmann, Gastroenterology and Infectious Diseases, Charlottenstr. 72, 14467 Potsdam, Germany
}

Received: 29 January 2010 Accepted: 21 June 2010

Published: 21 June 2010

\section{References}

1. Kimberlin DW, Whitley RJ: Varicella-zoster vaccine for the prevention of herpes zoster. NEngl J Med 2007, 356:1338-1343.

2. Hope-Simpson RE: The nature of herpes zoster: a long-term study and a new hypothesis. Proc R Soc Med 1965, 58:9-20.

3. Arvin A: Aging, immunity, and the varicella-zoster virus. NEngl J Med 2005, 352:2266-2267.

4. Volpi A, Gross G, Hercogova J, Johnson RW: Current management of herpes zoster: the European view. Am J Clin Dermatol 2005, 6:317-325.

5. Gnann JW Jr, Whitley RJ: Clinical practice: herpes zoster. N Engl J Med 2002, 347:340-346.

6. Johnson R, McElhaney J, Pedalino B, Levin M: Prevention of herpes zoster and its painful and debilitating complications. Int J Infect Dis 2007 11(Suppl 2):S43-S48.

7. Arvin AM: Varicella-zoster virus. Clin Microbiol Rev 1996, 9:361-381.

8. Schmader K, Gnann JW Jr, Watson CP: The epidemiological, clinical, and pathological rationale for the herpes zoster vaccine. J Infect Dis 2008, 197(Suppl 2):S207-S215

9. Opstelten W, Mauritz JW, de Wit NJ, van Wijck AJ, Stalman WA, van Essen GA: Herpes zoster and postherpetic neuralgia: incidence and risk indicators using a general practice research database. Fam Pract 2002, 19:471-475.

10. Dworkin RH, Gnann JW Jr, Oaklander AL, Raja SN, Schmader KE, Whitley RJ: Diagnosis and assessment of pain associated with herpes zoster and postherpetic neuralgia. J Pain 2008, 9(Suppl 1):S37-S44.

11. Johnson RW: Zoster-associated pain: what is known, who is at risk and how can it be managed? Herpes 2007, 14(Suppl 2):30A-34A.

12. Hornberger J, Robertus $\mathrm{K}$ : Cost-effectiveness of a vaccine to prevent herpes zoster and postherpetic neuralgia in older adults. Ann Intern Med 2006, 145:317-325.

13. Oster G, Harding G, Dukes E, Edelsberg J, Cleary PD: Pain, medication use, and health-related quality of life in older persons with postherpetic neuralgia: results from a population-based survey. J Pain 2005, 6:356-363.

14. Arvin AM: Varicella-zoster virus. In Fields Virology Volume 2. 4th edition. Edited by: Knipe DM, Howley PM. Philadelphia: Lippincott Williams \& Wilkins; 2001:2731-2768.

15. Johnson RW: Herpes zoster and postherpetic neuralgia: a review of the effects of vaccination. Aging Clin Exp Res 2009, 21:236-243.

16. Gauthier A, Breuer J, Carrington D, Martin M, Rémy V: Epidemiology and cost of herpes zoster and post-herpetic neuralgia in the United Kingdom. Epidemiol Infect 2009, 137:38-47.

17. Stein AN, Britt H, Harrison C, Conway EL, Cunningham A, Macintyre CR: Herpes zoster burden of illness and health care resource utilisation in the Australian population aged 50 years and older. Vaccine 2009, 27:520-529.

18. Katz J, Cooper EM, Walther RR, Sweeney EW, Dworkin RH: Acute pain in herpes zoster and its impact on health-related quality of life. Clin Infect Dis 2004, 39:342-348.

19. Coplan PM, Schmader K, Nikas A, Chan IS, Choo P, Levin MJ, Johnson G, Bauer M, Williams HM, Kaplan KM, Guess HA, Oxman MN: Development of a measure of the burden of pain due to herpes zoster and postherpetic neuralgia for prevention trials: adaptation of the brief pain inventory. J Pain 2004, 5:344-356.

20. Volpi A: Severe complications of herpes zoster. Herpes $2007,14($ Suppl 2):35A-39A.

21. World Health Organization: Constitution of the World Health Organization. Basic Documents. 45th edition. Geneva: WHO; 2006

22. University of Toronto: The Quality of Life Model. 2009 [http:// www.utoronto.ca/gol/concepts.htm].

23. Turk DC, Dworkin RH, Allen RR, Bellamy N, Brandenburg N, Carr DB, Cleeland C, Dionne R, Farrar JT, Galer BS, et al:: Core outcome domains for chronic pain clinical trials: IMMPACT recommendations. Pain 2003, 106:337-345.

24. Schmader K: Herpes zoster in the elderly: issues related to geriatrics. Clin Infect Dis 1999, 28:736-739.

25. Khanna D, Tsevat J: Health-related quality of life - an introduction. Am J Manag Care 2007, 13(Suppl 9):S218-S223.

26. Schmader KE, Sloane R, Pieper C, Coplan PM, Nikas A, Saddier P, Chan IS, Choo $P$, Levin MJ, Johnson G, et al:: The impact of acute herpes zoster pain and discomfort on functional status and quality of life in older adults. Clin J Pain 2007, 23:490-496. 
27. Norquist J, Nikas A, Saddier P, Choo P, Levin M, Oxman M, Schmader K: Measuring aspects of daily life in patients with herpes zoster. San Francisco, CA, USA; 2005. (Abstract). International Society for Quality of Life Research, 12th Annual Conference

28. Johnson RW, Wasner G, Saddier P, Baron R: Herpes zoster and postherpetic neuralgia: optimizing management in the elderly patient. Drugs Aging 2008, 25:991-1006.

29. Breuer J, Whitley R: Varicella zoster virus: natural history and current therapies of varicella and herpes zoster. Herpes 2007, 14(Suppl 2):25-29. [Erratum in Herpes 2007, 14: 74]

30. Katz J, Melzack R: Measurement of pain. Surg Clin North Am 1999 79:231-252.

31. Choo PW, Galil K, Donahue JG, Walker AM, Spiegelman D, Platt R: Risk factors for postherpetic neuralgia. Arch Intern Med 1997, 157:1217-1224.

32. Whitley RJ, Shukla S, Crooks RJ: The identification of risk factors associated with persistent pain following herpes zoster. J Infect Dis 1998, 178(Suppl 1):S71-S75.

33. Jung BF, Johnson RW, Griffin DR, Dworkin RH: Risk factors for postherpetic neuralgia in patients with herpes zoster. Neurology 2004, 62:1545-1551

34. Volpi A, Gatti A, Pica F, Bellino S, Marsella LT, Sabato AF: Clinical and psychosocial correlates of post-herpetic neuralgia. J Med Virol 2008 , 80:1646-1652

35. Pavan-Langston D: Ophthalmic zoster. In Varicella-Zoster Virus, Virology and Clinical Management Edited by: Arvin AM, Gershon AA. Cambridge Press; 2000:276-298

36. Lydick E, Epstein RS, Himmelberger D, White CJ: Herpes zoster and quality of life: a self-limited disease with severe impact. Neurology 1995, 45(Suppl 8):S52-S53.

37. Schmader K: Herpes zoster in older adults. Clin Infect Dis 2001, 32:1481-1486

38. Chidiac C, Bruxelle J, Daures JP, Hoang-Xuan T, Morel P, Leplège A, Hasnaoui A El, de Labareyre C: Characteristics of patients with herpes zoster on presentation to practitioners in France. Clin Infect Dis 2001, 33:62-69.

39. Oaklander AL, Bowsher D, Galer B, Haanpää M, Jensen MP: Herpes zoster itch: preliminary epidemiologic data. J Pain 2003, 4:338-343.

40. van Seventer R, Sadosky A, Lucero M, Dukes E: A cross-sectional survey of health state impairment and treatment patterns in patients with postherpetic neuralgia. Age Ageing 2006, 35:132-137.

41. Schmader KE: Epidemiology and impact on quality of life of postherpetic neuralgia and painful diabetic neuropathy. Clin J Pain 2002, 18:350-354.

42. Mauskopf J, Austin R, Dix L, Berzon R: The Nottingham Health Profile as a measure of quality of life in zoster patients: convergent and discriminant validity. Qual Life Res 1994, 3:431-435.

43. Schmader K: Herpes zoster and postherpetic neuralgia in older adults. Clin Geriatr Med 2007, 23:615-632. vii-viii

44. Johnson RW, Whitton TL: Management of herpes zoster (shingles) and postherpetic neuralgia. Expert Opin Pharmacother 2004, 5:551-559.

45. Kang JH, Ho JD, Chen YH, Lin HC: Increased risk of stroke after a herpes zoster attack: a population-based follow-up study. Stroke 2009, 40:3443-3448.

46. Lin HC, Chien CW, Ho JD: Herpes zoster ophthalmicus and the risk of stroke: a population-based follow-up study. Neurology 2010, 74:792-797.

47. Yawn BP, Saddier P, Wollan PC, St Sauver JL, Kurland MJ, Sy LS: A population-based study of the incidence and complication rates of herpes zoster before zoster vaccine introduction. Mayo Clin Proc 2007, 82:1341-1349. [Erratum in: Mayo Clin Proc 2008; 83: 255]

48. di Luzio Paparatti U, Arpinelli F, Visonà G: Herpes zoster and its complications in Italy: an observational survey. J Infect 1999, 38:116-120

49. Weinke T, Edte S, Schmitt S, Lukas K: Impact of herpes zoster and postherpetic neuralgia on patients' quality of life: a patient-reported outcomes survey. J Public Health 2010.

50. Álvarez Pasquín MJ, Morató Agustí ML, San-Martín Rodríguez M, y Grupo EPIZOSTER: Impacto del herpes zóster con o sin neuralgia postherpética en la calidad de vida de los pacientes. 2008 [http:// congres02008.semfyc.gatewaysc.com/archivos/file/Madrid202008/ Posters\%20web\%20final.pdf]. Madrid, Spain [Impact of HZ with or without PHN on patients' QoL]. Abstract. Congress Sociedad Española de Medicina de Familia y Comunitaria, Accessed 7 October 2009

51. Baanders AN, Heijmans MJ: The impact of chronic diseases: the partner's perspective. Fam Community Health 2007, 30:305-317.

52. Scott FT, Johnson RW, Leedham-Green M, Davies E, Edmunds WJ, Breuer J: The burden of Herpes Zoster: a prospective population based study. Vaccine 2006, 24:1308-1314.

53. van Hoek AJ, Gay N, Melegaro A, Opstelten W, Edmunds WJ: Estimating the cost-effectiveness of vaccination against herpes zoster in England and Wales. Vaccine 2009, 27:1454-1467.

54. de Melker $H$, Berbers $G$, Hahné $S$, Rümke $H$, van den Hof $S$, de Wit $A$, Boot $H$ : The epidemiology of varicella and herpes zoster in The Netherlands: implications for varicella zoster virus vaccination. Vaccine 2006 24:3946-3952.

55. Brisson M, Edmunds WJ: Epidemiology of varicella-zoster virus in England and Wales. J Med Virol 2003, 70(Suppl 1):S9-S14.

56. Paul $E$, Thiel T: Epidemiology of varicella zoster infection. Results of a prospective study in the Ansbach area. Hautarzt 1996, 47:604-609. [in German]

57. Edmunds WJ, Brisson M, Rose JD: The epidemiology of herpes zoster and potential cost-effectiveness of vaccination in England and Wales. Vaccine 2001, 19:3076-3090.

58. Lin F, Hadler JL: Epidemiology of primary varicella and herpes zoster hospitalizations: the pre-varicella vaccine era. J Infect Dis 2000, 181:1897-1905

59. McElhaney JE: Herpes zoster: a common disease that can have a devastating impact on patients' quality of life. Expert Rev Vaccines 2010, 9:27-30

60. Dworkin RH: Post-herpetic neuralgia. Herpes 2006, 13(Suppl 1):21A-27A

61. Harpaz R, Ortega-Sanchez IR, Seward JF: Prevention of herpes zoster: recommendations of the Advisory Committee on Immunization Practices (ACIP). MMWR Recomm Rep 2008, 57:1-30. [Erratum in MMWR Recomm Rep 2008; 57: 779]

62. Galluzzi KE: Management strategies for herpes zoster and postherpetic neuralgia. J Am Osteopath Assoc 2007, 107(Suppl 1):S8-S13.

63. Wood MJ, Kay R, Dworkin RH, Soong SJ, Whitley RJ: Oral acyclovir therapy accelerates pain resolution in patients with herpes zoster: a metaanalysis of placebo-controlled trials. Clin Infect Dis 1996, 22:341-347.

64. Li Q, Chen N, Yang J, Zhou M, Zhou D, Zhang Q, He L: Antiviral treatment for preventing postherpetic neuralgia. Cochrane Database Syst Rev 2009, 2:CD006866.

65. Dworkin RH, Johnson RW, Breuer J, Gnann JW, Levin MJ, Backonja M, Betts RF, Gershon AA, Haanpaa ML, McKendrick MW, Nurmikko TJ, et al:: Recommendations for the management of herpes zoster. Clin Infect Dis 2007, 44(Suppl 1):S1-26.

66. Johnson RW, McElhaney J: Postherpetic neuralgia in the elderly. Int Clin Pract 2009, 63:1386-1391.

67. Christo PJ, Hobelmann G, Maine DN: Post-herpetic neuralgia in older adults: evidence-based approaches to clinical management. Drugs Aging 2007, 24:1-19.

68. Finnerup NB, Otto M, McQuay HJ, Jensen TS, Sindrup SH: Algorithm for neuropathic pain treatment: an evidence-based proposal. Pain 2005, 118:289-305.

69. Lieu TA, Ortega-Sanchez I, Ray GT, Rusinak D, Yih WK, Choo PW, Shui I, Kleinman K, Harpaz R, Prosser LA: Community and patient values for preventing herpes zoster. Pharmacoeconomics 2008, 26:235-249.

70. Oxman MN, Levin MJ, Johnson GR, Schmader KE, Straus SE, Gelb LD, Arbeit RD, Simberkoff MS, Gershon AA, Davis LE, et al:: A vaccine to prevent herpes zoster and postherpetic neuralgia in older adults. $N$ Engl J Med 2005, 352:2271-2284.

71. Oxman MN, Levin MJ, Shingles Prevention Study Group: Vaccination against herpes zoster and postherpetic neuralgia. J Infect Dis 2008, 197(Suppl 2):S228-S236

72. Schmader K, Saddier P, Johnson G, et al: The effect of a zoster vaccine on interference of herpes zoster with activities of daily living (ADL). Toronto, Canada; 2006. Abstract 859, 44th Annual Meeting of the Infectious Diseases Society of America

73. Gnann JW Jr: Vaccination to prevent herpes zoster in older adults. $J$ Pain 2008, 9:S31-S36.

74. Liesegang TJ: Varicella-zoster virus eye disease. Cornea 1999, 18:511-531 
75. Hempenstall K, Nurmikko TJ, Johnson RW, A'Hern RP, Rice AS: Analgesic therapy in postherpetic neuralgia: a quantitative systematic review. PLoS Med 2005, 2:e164.

76. Gnann JW Jr: Antiviral therapy for herpes zoster. Herpes 2006, 13(Suppl 1): $16 \mathrm{~A}-20 \mathrm{~A}$

77. Tyring S, Barbarash RA, Nahlik JE, Cunningham A, Marley J, Heng M, Jones $T$, Rea T, Boon R, Saltzman R: Famciclovir for the treatment of acute herpes zoster: effects on acute disease and postherpetic neuralgia. $A$ randomized, double-blind, placebo-controlled trial. Collaborative Famciclovir Herpes Zoster Study Group. Ann Intern Med 1995, 123:89-96.

78. Beutner KR: Valacyclovir: a review of its antiviral activity, pharmacokinetic properties, and clinical efficacy. Antiviral Res 1995 28:281-290.

79. Quan D, Hammack BN, Kittelson J, Gilden DH: Improvement of postherpetic neuralgia after treatment with intravenous acyclovir followed by oral valacyclovir. Arch Neurol 2006, 63:940-942.

80. Wood MJ, Johnson RW, McKendrick MW, Taylor J, Mandal BK, Crooks J: A randomized trial of acyclovir for 7 days or 21 days with and without prednisolone for treatment of acute herpes zoster. N Engl J Med 1994, 330:896-900.

81. Whitley RJ, Gnann JW Jr, Weiss HL, Soong SJ: Unique clinical trial design: combination acyclovir plus prednisone therapy of localized zoster in the normal host. Antiviral Res 1996, 29:67-68.

82. Dworkin RH, Corbin AE, Young JP Jr, Sharma U, LaMoreaux L, Bockbrader $H$, Garofalo EA, Poole RM: Pregabalin for the treatment of postherpetic neuralgia: a randomized, placebo-controlled trial. Neurology 2003, 60:1274-1283.

83. Sabatowski R, Gálvez R, Cherry DA, Jacquot F, Vincent E, Maisonobe P, Versavel M: Pregabalin reduces pain and improves sleep and mood disturbances in patients with post-herpetic neuralgia: results of a randomised, placebo-controlled clinical trial. Pain 2004, 109:26-35.

84. Rowbotham M, Harden N, Stacey B, Bernstein P, Magnus-Miller L: Gabapentin for the treatment of postherpetic neuralgia: a randomized controlled trial. JAMA 1998, 280:1837-1842.

85. Pavan-Langston D: Herpes zoster antivirals and pain management. Ophthalmology 2008, 115(Suppl 2):S13-S20.

86. Backonja M, Wallace MS, Blonsky ER, Cutler BJ, Malan P Jr, Rauck R, Tobias J: NGX-4010, a high-concentration capsaicin patch, for the treatment of postherpetic neuralgia: a randomised, double-blind study. Lancet Neurol 2008, 7:1 106-1112. NGX-4010 C116 Study Group [Erratum in Lancet Neurol 2009; 8: 31]

87. Manabe H, Dan K, Hirata K, Hori K, Shono S, Tateshi S, Ishino H, Higa K: Optimum pain relief with continuous epidural infusion of local anesthetics shortens the duration of zoster-associated pain. Clin J Pain 2004, 20:302-308

88. Pasqualucci A, Pasqualucci V, Galla F, De Angelis V, Marzocchi V, Colussi R, Paoletti F, Girardis M, Lugano M, Del Sindaco F: Prevention of postherpetic neuralgia: acyclovir and prednisolone versus epidural local anesthetic and methylprednisolone. Acta Anaesthesiol Scand 2000 44:910-918.

89. van Wijck AJ, Opstelten W, Moons KG, van Essen GA, Stolker RJ, Kalkman CJ, Verheij TJ: The PINE study of epidural steroids and local anaesthetics to prevent postherpetic neuralgia: a randomised controlled trial. Lancet 2006, 367:219-224.

\section{Pre-publication history}

The pre-publication history for this paper can be accessed here: http://www.biomedcentral.com/1741-7015/8/37/prepub

doi: $10.1186 / 1741-7015-8-37$

Cite this article as: Johnson et al., The impact of herpes zoster and post-herpetic neuralgia on quality-of-life BMC Medicine 2010, 8:37

\section{Submit your next manuscript to BioMed Central} and take full advantage of:

- Convenient online submission

- Thorough peer review

- No space constraints or color figure charges

- Immediate publication on acceptance

- Inclusion in PubMed, CAS, Scopus and Google Scholar

- Research which is freely available for redistribution

Submit your manuscript at www.biomedcentral.com/submit
C Biomed Central 